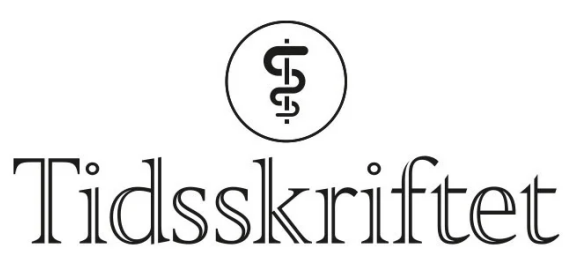

DEN NORSKE LEGEFORENING

\title{
Tre bølger i Bærum
}

LEDER

GUTTORM BRATTEB $\varnothing$

guttorm.brattebo@helse-bergen.no

Guttorm Brattebø er seksjonsoverlege ved Kirurgisk serviceklinikk, Haukeland universitetssjukehus, og professor i traumatologi ved Universitetet i Bergen. Han er norsk representant i European Board of Anaesthesiology.

Forfatteren har fylt ut ICMJE-skjemaet og oppgir ingen interessekonflikter.

\section{Kunnskap om hvordan det har gått med covid-19-pasienter innlagt ved et lokalsykehus i Oslo-området gir viktig informasjon for forberedelsene til neste koronabølge.}

I Tidsskriftet presenterer nå Myrstad og medarbeidere sykdomsforløp og behandling for de totalt 300 covid-19-pasientene som ble innlagt ved Bærum sykehus i løpet av de tre første «bølgene» med koronasmitte i 2020 og 2021 (1).

Bærum sykehus er et forholdsvis stort lokalsykehus som dekker knapt 200 ooo innbyggere. For en avdeling med vel go sengeplasser, hvorav åtte for pasienter med behov for intensiv overvåking og behandling, har nok belastingen med disse pasientene vært betydelig.

Ikke overraskende hadde to tredjedeler av de innlagte pasientene respirasjonssvikt,hvorav $15 \%$ (31 pasienter) havnet på respirator. Dødeligheten blant de 15 pasientene som

fikkrespiratorbehandling i siste bølge, var $27 \%$ (4 av dem døde), noe som er lavt (2 2,3 ). I de to siste bølgene fikk drøye fire femtedeler av pasientene med respirasjonssvikt steroidbehandling, slik det er anbefalt (4). Dødeligheten i sykehus falt gjennom de tre periodene, og var i siste bølge under $5 \%$. Dette kan, slik forfatterne diskuterer, skyldes at gjennomsnittsalderen blant pasientene da var noe lavere sammenlignet med den første bølgen, og at mange i den første bølgen var skrøpelige (5). Mortaliteten i første bølge kan også henge sammen med at en femtedel av pasientene ikke fikk tromboseprofylakse. Tegn på koagulasjonsforstyrrelser har prognostisk betydning ved covid-19, og tromboseprofylakse er både viktig og utfordrende $(\underline{6}, 7$.$) .$

Det er krevende å beslutte hvilket behandlingsnivå man skal velge for en pasient med alvorlig covid-19. Her trenger vi enda bedre prognostiske hjelpemidler, ikke minst dersom vi virkelig havner i en krisesituasjon der vi ikke kan tilby alle den best dokumenterte behandlingen. Basert på pasienters habitualtilstand og kliniske tilstand, trenger både kommunehelsetjenesten og sykehus et velfundert grunnlag for å vurdere prognose og behandlingsnivå, eksempelvis hvem som skal tilbys respiratorbehandling $(\underline{2}, 3,5)$. 
Når dette skrives (17.12.2021), er vi inne i en ny bølge med koronasmitte, og antallet sykehusinnlagte pasienter er høyere enn noensinne. Hva som vil skje videre med utbredelsen av den svært smittsomme omikronvarianten, er usikkert. Det store spørsmålet er hvor sykdomsfremkallende varianten vil være i en befolkning som er forholdsvis gjennomvaksinert. I denne sammenhengen er det verdt å minne om at vi fortsatt er i utredningsfasen når det gjelder intensivkapasitet i Norge (요). Faktisk er ikke intensivkapasiteten vår større nå enn for to år siden. Det er en skandale.

«Intensivkapasiteten vår er ikke større nå enn for to år siden. Det er en skandale»

Et nærliggende spørsmål er om ikke myndighetene kunne ha benyttet den forholdsvis fredelige fasen vi har vært inne i, mer aktivt. Antallet tilgjengelige intensivsenger beror på fysisk plass ved intensivenhetene våre, men også på tilgjengelige helsearbeidere med nødvendig kompetanse. Vi vet for eksempel at mange sykepleiere med intensivutdanning ikke jobber ved intensivavdelinger. Hva skal til for at disse vil vurdere å begynne å arbeide i den funksjonen de utdannet seg til?

Takket være denne og tidligere rapporter fra Bærum sykehus vet vi nå mer om hvordan det gikk med en stor gruppe covid-19-pasienter som fikk behandling ved dette sykehuset. Sammen med data fra pandemiregisteret er dette viktig informasjon, ikke minst for andre sykehus som nå kan sammenligne resultatene med egne funn.

Hvordan har de sykehusene som har hatt mange pasienter, klart å løse oppgavene med organisering av personell og utnyttelse av areal? Hvilke konsekvenser har håndteringen av pandemien medført for andre pasientgrupper, og for de mange helsearbeidere som står midt i situasjonen? Den arbeidsmessige og psykososiale belastningen har kanskje vært større enn det mange har villet erkjenne. Dette må vi få mer kunnskap om.

Når vi ser hvilke store beløp som går med til å kompensere for de nasjonale smitteverntiltakene, er det et tankekors at helsetjenesten ikke har fått mer til å bemanne opp og bygge beredskap. Økt beredskap er noe «alle» ønsker, men som få er villige til å betale for. Tilleggsbevilgningen på 7oo millioner kroner til spesialisthelsetjenesten i det reviderte statsbudsjettet er et stort beløp, men dessverre ikke mye å bygge beredskap for. Kanskje var koronakommisjonen for snill i sin evaluering når den konkluderte med at myndighetene har håndtert pandemien på en god måte (9).

Det er grenser for hvor lenge helsetjenesten kan klare å leve i en truende unntakstilstand som nå.

\section{LITTERATUR}

1. Myrstad M, Rønningen PS, Tveita A et al. Tre bølger med covid-19 på et norsk lokalsykehus. Tidsskr Nor Legeforen 2022; 142. doi:10.4045/tidsskr.21.0750. [CrossRef]

2. Li J, Huang DQ, Zou B et al. Epidemiology of COVID-19: A systematic review and meta-analysis of clinical characteristics, risk factors, and outcomes. J Med Virol 2021; 93: 1449-58. [PubMed][CrossRef]

3. Gallo Marin B, Aghagoli G, Lavine K et al. Predictors of COVID-19 severity: A literature review. Rev Med Virol 2021; 31: 1-10. [PubMed][CrossRef]

4. Alhazzani W, Evans L, Alshamsi F et al. Surviving Sepsis Campaign Guidelines on the management of adults with coronavirus disease 2019 (COVID-19) in the ICU: First update. Crit Care Med 2021; 49: e219-34. [PubMed][CrossRef]

5. Pranata R, Henrina J, Lim MA et al. Clinical frailty scale and mortality in COVID-19: A systematic review and dose-response meta-analysis. Arch Gerontol Geriatr 2021; 93: 104324. [PubMed][CrossRef]

6. Asakura H, Ogawa H. COVID-19-associated coagulopathy and disseminated intravascular coagulation. Int J Hematol 2021; 113: 45-57. [PubMed][CrossRef] 
7. Kvåle R, Azrakhsh NA, Mohn KGI et al. Covid-19 og venøs tromboembolisme - profylakse og behandling. Tidsskr Nor Legeforen 2020; 140. doi: 10.4045/tidsskr.20.0440. [PubMed][CrossRef]

8. Kalveland J. Starter stor utredning av intensivkapasitet. Dagens Medisin 13.12.2021. https://www.dagensmedisin.no/artikler/2021/12/13/slik-skal-intensivkapasiteten-utredes/ Lest 17.12.2021.

9. NOU 2021:6. Koronakommisjonens rapport. https://www.koronakommisjonen.no/kommisjonensrapport-og-presentasjoner/ Lest 17.12.2021.

Publisert: 27. desember 2021. Tidsskr Nor Legeforen. DOI: 10.4045/tidsskr.21.0901

(C) Tidsskrift for Den norske legeforening 2023. Lastet ned fra tidsskriftet.no 26. april 2023. 